1 Meredith HV Body weight at birth of viable human infants: a worldwide comparative treatise. Hum Biol 1970;42:217-64.

Macfarlane A, Mugford M. Birth counts. Statistics of pregnancy and childbirth. London: HMSO, 1984

3 Chubb CW. A large child. BrMed f 1879;i:143.

4 Modanlou HD, Dorchester WL, Thorosian A, Freeman RK. Macrosomia-maternal, fetal, and neonatal implications. Obstet Gynecol 1980;55:420-4.

Oats JN, Abell DA, Beischer NA, Broomhall GR. Maternal glucose tolerance during pregnancy with excessive size infants. Obstet Gynecol 1980;55:184-6.

6 Boyd ME, Usher RH, McLean FH. Fetal macrosomia: prediction, risks, proposed management. Obstet Gynecol 1983;61:715-22.

Stevenson DK, Hopper AO, Cohen RS, Bucalo LR, Kerner JA, Sunshine P. Macrosomia: causes and consequences. F Pediatr 1982;100:515-20.

8 Gruenwald P. Growth of the human foetus. In: McLaren A, ed. Advances in reproductive physiology. Vol 2. London: Logos Press, 1967:279-309.

Olsen SF, Hansen HS, Sørensen TIA, et al. Intake of marine fat, rich in (n-3)-polyunsaturated fatty acids, may increase birthweight by prolonging gestation. Lancet 1986;ii:367-9.

10 Klebanoff MA, Mills JL, Berendes HW. Mother's birthweight as a predictor of macrosomia. Am 7 Obstet Gynecol 1985;153:253-7.

11 Scott A, Moar V, Ounsted $M$. The relative contribution of different maternal factors in large-forgestational-age pregnancies. Eur $\mathcal{F}$ Obstet Gynec Reprod Biol 1982;13:269-77.

12 Parks DG, Ziel HK. Macrosomia. A proposed indication for primary cesarean section. Obstet Gynecol 1978;52:407-9.

13 Svigos JM. The macrosomic infant. A high-risk complication. Med f Aust 1981;1:245-6.

14 Tamura RK, Sabbagha RE, Depp R, Dooley SL, Socol ML. Diabetic macrosomia: accuracy of third trimester ultrasound. Obstet Gynecol 1986;67:828-32.

15 Paneth N. Birth and the origins of cerebral palsy. $N$ Engl f Med 1986;315:124-6.

16 Jagani N, Schulman H, Chandra P, Gonzalez R, Fleischer A. The predictability of labor outcome from a comparison of birth weight and x-ray pelvimetry. Am f Obstet Gynecol 1981;139:507-11. Benedetti TJ, Gabbe SG. Shoulder dystocia. A complication of fetal macrosomia and prolonged second stage of labor with midpelvic delivery. Obstet Gynecol 1978;52:526-9.

8 Bennet GC, Harrold AJ. Prognosis and early management of birth injuries to the brachial plexus. BrMed f 1976;: 1520-1

19 Philpott RH. Obstructed labour. Clin Obstet Gynaecol 1980:7:609-11.

19 Prile RH. Obstred labour. Clin Obstet Gynaecol 1980:7.609-11. among the pedis of yesteryear. S Afr Med f 1982;61:842.

21 Prochownick L. Ueber Ernährungscuren in der Schwangerschaft. Therapeutische Monatshefte 1901;15:387-403.

22 Smith CA. The effect of wartime starvation in Holland upon pregnancy and its product. $A m \mathcal{F}$ Obstet Gynecol 1947;53:599-608.

23 Antonov AN. Children born during the siege of Leningrad in 1942. F Pediatr 1947;30:250-9.

24 Kerr-Grieve JF, Campbell-Brown BM, Johnstone FD. Dieting in pregnancy. A study of the effect of a high protein low carbohydrate diet on birthweight on an obstetric population. In Sutherland HW, Stowers JM, eds. Carbohydrate metabolism in pregnancy and the newborn 1978. Berlin: Springer, 1979:518-34

25 Borberg C, Gillmer MDG, Brunner EJ, Gunn PJ, Williams MJH, Beard RW. Obesity in pregnancy - dietary advice and neonatal outcome. In: Wharton BA, ed. Topics in paediatrics 2. Nutrition in childhood. London: Pitman Medical, 1980:8-21.

26 Studd J, Cardozo L. Evaluation of induction of labour. In: Studd J, ed. The management of labour. Oxford: Blackwell Scientific Publications, 1985:123-32.

27 Feldman GB, Freiman JA. Prophylactic cesarean section at term? N Engl f Med 1985;312:1264-7.

\section{Herpes simplex virus encephalitis in children}

The development of more effective and safer treatment for herpes simplex virus encephalitis has made early diagnosis imperative as in most cases delay leads to devastating disability or death. The outcome depends on the degree of brain dysfunction when treatment is started.

A recent report from Melbourne illustrates how difficult diagnosis may be in children. ${ }^{2}$ In none of five cases had the diagnosis been considered on first presentation to hospital. The initial clinical features were subtle and non-specific, and laboratory investigations, including examination of cerebrospinal fluid, were unhelpful. Electroencephalography showed focal abnormalities in the four patients who were tested, but the abnormalities were not diagnostic and in one case were initially misleading. Only one of the patients recovered fully, and one patient died.

Many paediatricians have had similar experiences, and these cases repay analysis. Three patients had had early and persistent focal seizures, and another had had a prolonged generalised convulsion. Early focal neurological deficit occurred in only one patient, who later developed a hemiparesis. Four patients had computed tomograms, and three of the scans showed low density areas, the importance of which was not realised in one case. The fourth scan showed only cerebral oedema. The diagnosis was made by brain biopsy in two cases. Examination of cerebrospinal fluid was abnormal in each case, which is consistent with generd experience, but the initial findings were not diagnostie Antibodies to herpes simplex virus developed in one child who had two specimens of cerebrospinal fluid collecteeg 12 days apart. In another child a presumptive diagnosis wa made since serum collected during convalescence showed significant rise in antibody titre to herpes simplex virus type when compared with serum collected during the acute phase of the condition; antibodies were not detected in cerebro spinal fluid. In the fifth and fatal case, a neonate, herpe simplex virus was found only in skin vesicle fluid.

A paediatrician should consider herpes simplex viru encephalitis as a diagnosis in any febrile child with foctit seizures and focal neurological signs associated with $\operatorname{pr} \Phi$ gressive deterioration in consciousness. Herpetic lesions obviously heighten suspicion but are rare in patients with herpes simplex virus encephalitis. Neither computed tomography nor electroencephalography is diagnostic, and normal computed tomogram does not exclude the diseas since abnormalities may appear only late. Electroencephalos. graphy is a more sensitive tool: focal changes and periodif complexes may be seen between the second and 15th day of the disease ${ }^{3}$ but rarely after the second week. ${ }^{4}$ Although thi cerebrospinal fluid is rarely normal, the pleocytosis an $\$$ raised protein concentration often found are not diagnostic $\vec{\omega}$

American $^{5}$ and Scandinavian ${ }^{6}$ studies show that corpo centrations of antibodies to herpes simplex virus in cerebro spinal fluid usually rise too late to help guide treatment. The rapid appearance of $\operatorname{IgM}$ antibody to herpes simplex virus type 1 in the cerebrospinal fluid and serum confirmed the diagnosis in two infants in one report,' but this seems unusual. Specimens of serum and cerebrospinal fluid musin be obtained both during the acute stage of the disease and if convalescence, and the titres of antibodies to herpes simplege virus measured. Results from the acute phase are inadequate on their own. A fourfold or greater increase in the cerebro spinal fluid to serum antibody ratio compared with the corresponding ratio for reference (measles) virus antibody 용 taken as evidence of intrathecal synthesis of antibodies ti herpes simplex virus.

Brain biopsy is the only method that will give a firm diagnosis quickly in the early treatable phase of the illness In the United States it is recommended in all patients with suspected herpes simplex virus encephalitis. An advantage of the technique is that other unsuspected treatable disease may be found. Doctors outside the United States aro reluctant, however, to resort to craniotomy and brain biopsy? especially in children, and a therapeutic trial with acyclovir therefore justified-provided all other methods are used to confirm or exclude the diagnosis of herpes simplex virus encephalitis. Acyclovir is a more effective and safer treaf ment than its predecessors, idoxuridine and cytarabine, and is superior to vidarabine. $9^{10}$ The therapeutic "overkill" of the trial seems a worthwhile price to pay for effectively treating the few affected individuals.

The failure to obtain, or even to seek, laboratory endorse ment of the diagnosis has, however, been rightly criticised data from soundly diagnosed cases are needed for our bette understanding of the disease. If we accept, as probably most British paediatricians and child neurologists do, that braig biopsy is neither necessary nor justified before starting acyclovir in a child with suspected herpes simplex virug encephalitis we should strive to reach or exclude the diagnosis by other less drastic methods. If the suspecteg case is treated with acyclovir the delay in obtainin diagnostic results from serology or computed tomography $\frac{8}{8}$ 
not important provided every effort is made to collect the data.

Consultant Neurologist, Hospital for Sick Children,

E M BRETT

Great Ormond Street, London WCIN 3JH

1 Whitley RJ, Seng-Jaw S, Hirsch M, et al. Herpes simplex encephalitis: vidarabine therapy and diagnostic problems. N Engl f Med 1981;304:313-8.

McCrossin DB, Gilbert GL. Herpes simplex virus encephalitis in children. Med $\mathcal{J}$ Aust 1986;144:711-3.

3 Upton A, Gumpert J. Electroencephalography in herpes simplex encephalitis. Lancet 1970; 650-2.

4 Schauseil-Zipf U, Harden A, Hoare R, et al. Early diagnosis of herpes simplex encephalitis in childhood. Eur I Pediatr 1982;138:154-61.

Nahmias AJ, Whitley RJ, Visintine AN, et al. Herpes simplex virus encephalitis: laboratory evaluations and their diagnostic significance. I Infect Dis 1982;145:829-36.

6 Koskiniemi A, Vaheri A, Taskinen E. Cerebrospinal fluid alterations in herpes simplex virus encephalitis. Rev Infect Dis 1984;6:608-18.

Dwyer DE, O'Flaherty SO, Packham D, et al. Herpes simplex encephalitis in infants. Med f Aust 1986;144:714-5.

8 Longson M. Herpes simplex encephalitis. In: Matthews WB, Glaser GH, eds. Recent advances in linical neurology. Vol 4. Edinburgh: Churchill Livingstone, 1984:123-39.

9 Skoldenberg B, Forsgren M, Alestig K, et al. Acyclovir versus vidarabine in herpes simplex encephalitis. Randomised multicentre study in consecutive Swedish patients. Lancet 1984;ii: 707-11.

10 Whitley RJ, Alford CA, Hirsch MS. Vidarabine versus acyclovir therapy in herpes simplex encephalitis. N Engl f Med 1986;314:144-9.

\section{Carcinoma in situ of the testis}

The contralateral testes of men with testicular cancer and testes from infertile men and those with a history of maldescent may contain premalignant cells-carcinoma in situ. ${ }^{1}$ Detection of those cells may allow the early cancer to be cured,$^{2}$ and a recent meeting in Copenhagen reviewed the possibilities. ${ }^{3}$

Skakkebaek, who first described carcinoma in situ of the testis, has proposed calling the condition "gonocytoma in situ" to reflect the similarities between the premalignant cells and the primordial germ cells (or gonocytes) in the embryonic gonad. ${ }^{4}$ Some researchers believe that carcinoma in situ is the precursor of all germ cell tumours with the possible exception of spermatocytic seminoma. This theory has arisen because carcinoma in situ has the potential to progress to both seminomatous and non-seminomatous germ cell tumours $^{56}$ and because atypical cells may be found in cryptorchid testes from prepubescent boys.

Testicular biopsy is the only reliable way to detect carcinoma in situ, although the abnormal cells may be missed. The cells do, however, seem to be spread through the testis and are therefore likely to be detected by random biopsy $^{8}$ : none of 473 men with testicular cancer who had negative biopsy examinations of the contralateral testis went on to develop tumours. ${ }^{9}$ The diagnosis also depends on good specimen preparation, and a new development is using immunoperoxidase and antibodies against placental alkaline phosphatase. This appears to stain carcinoma in situ cells as well as seminoma cells.

Carcinoma in situ is most common in seminiferous tubules adjacent to a germ cell tumour but may be present in about $5 \%$ of the contralateral testes from men with tumours (p 1398). It may also occur in $2 \%$ of biopsy specimens from adult men with a history of maldescent of the testis ${ }^{9}$ and in $0 \cdot 4-1 \%$ of specimens from infertile men. ${ }^{10-12}$ Reports of carcinoma in situ have come from Europe, ${ }^{10-13}$ the USSR, ${ }^{14}$ North America, ${ }^{15}$ and Japan, ${ }^{16}$ but there have been no prospective studies. The fourth group of men at risk have gonadal dysgenesis, androgen insensitivity, or a $45 \mathrm{XO}$, $46 \mathrm{XY}$ karotype. In these rare disorders the risk may be as high as $80 \% .^{17}$
The risk of carcinoma in situ progressing to a germ cell tumour is substantial. ${ }^{10}$ In a series from London eight men with carcinoma in situ were detected among 2043 infertile men who underwent biopsy and six have subsequently developed tumours. ${ }^{10}$

Men with gonadal dysgenesis should certainly undergo biopsy, but which other men should is not yet agreed. Von der Masse and others ( $p$ 1398) recommend that surgeons should take a biopsy specimen from the contralateral testes from all men with testicular cancer. Such a policy would certainly teach us about the effect of chemotherapy on carcinoma in situ, which is important because the testis is said to be a sanctuary site and the current trend is to use shorter and less toxic drug regimens. Men with metastases who will receive chemotherapy anyway probably do not need biopsy. Doctors recommending orchidectomy and then surveillance rather than chemotherapy or radiotherapy for men with early stage germ cell tumours should consider biopsy of the contralateral testis. ${ }^{18} \mathrm{My}$ policy is to perform biopsy of the contralateral testis at the time of orchidectomy if the tumour seems to be localised. I judge which tumours are at an early stage from clinical examination, chest radiography, and abdominal ultrasonography, and I accept that subsequent detailed investigation may prove me wrong.

Deciding whether men with testicular maldescent or infertility should undergo biopsy is more difficult. The incidence of testicular maldescent appears to be increasing in England and Wales (p 1401) (19 $^{9}$ and in Scotland, ${ }^{20}$ and, worryingly, early orchidopexy may not protect against infertility. ${ }^{21}$ Danish experience suggests that infertile men at risk of carcinoma in situ usually have no azospermia but a low sperm concentration (less than 20 millions per $\mathrm{ml}$ ) and reduced testis volume (less than $12 \mathrm{ml}$ ). ${ }^{3}$ They may also have a history of testicular pain associated with a decrease and then an increase in testicular size. Self examination of the testis ${ }^{22}$ may thus help in diagnosis, and further help may come from the World Health Organisation task force on infertility adapting the Praadar orchidometer to make it more suitable for examining adult men. Ultrasonography and nuclear magnetic resonance are currently being evaluated as noninvasive methods of screening, ${ }^{3}$ but other techniques would be welcome.

The British reluctance to search for carcinoma in situ may result partly from lack of awareness of the condition and partly because the true risk of progression is only now becoming apparent. Also doctors have hesitated to recommend bilateral orchidectomy to young men with a unilateral tumour and contralateral carcinoma in situ or a unilateral orchidectomy to men with infertility. A recent preliminary report from Denmark that low dose irradiation $(20 \mathrm{~Gy})$ will abolish carcinoma in situ is an exciting development that needs confirmation. ${ }^{23}$

Standard treatment remains orchidectomy, but low dose radiotherapy seems to be an option for men with bilateral carcinoma in situ or carcinoma in situ in the single remaining testis. Chemotherapy regimens that include platinum will probably abolish carcinoma in situ in the contralateral testis, but we lack data.

Carcinoma in situ of the testis is now clearly described, and the men at risk have been defined. Now the knowledge must be used to prevent tumours and to reduce the numbers of men with metastatic disease.

T B HARGREAVE

Senior Lecturer,

Department of Urology,

Western General Hospital,

Edinburgh EH4 2XU 